\title{
Chapter 4 \\ The Ili River Delta: Holocene \\ Hydrogeological Evolution and Human Colonization
}

\author{
Jean-Marc Deom, Renato Sala and Anne Laudisoit
}

\begin{abstract}
Extensive survey of paleocourses of the Ili delta discovered archaeological findings that, chronologically attributed and systematized, allowed the historical reconstruction of the human occupation of the delta. Until recently the colonization was believed to have begun only during medieval times. We argue it began much earlier at the start of the Bronze Age of Kazakhstan (second half of the III millennium BC) under the impulse of new economical activities based on stockbreeding and bronze metallurgy. The basic method of research consisted in surveys, collection of surface finds and documentation of hydrogeological and climatic data. The correlation between the two types of information gives an idea of the factors that influenced the distribution of habitats, mostly represented by winter camps. Their number and concentration change by epoch, pointing to changes in both cultural proclivities and environmental factors. The understanding of the whole historical process requires background knowledge of the hydrological history of the Ili delta, a complex system involving active distributaries and intermittent or inactive paleo-courses, and showing the anticlockwise rotation of 5 successive deltas. Generally speaking, arid climate phases stabilize the delta, pluvial phases favor changes in various directions. Human colonization concerned the two Holocene deltas preceding the modern one: relict terraces of the Uzunaral delta (8-4 ka BP) and terraces of mild active distributaries of the Bakanas delta (4000-250 BP), subject during the last 4000 years to complex geomorphological and hydrological changes that, when reconstructed and correlated with the distribution of finds, explain the location of habitats and allow the mutual chronological attribution of geological and cultural deposits.
\end{abstract}

Keywords Ili river delta $\cdot$ Geological history $\cdot$ Holocene $\cdot$ Human colonization Settlement pattern $\cdot$ Pastoralist-metallurgic transhumances

J.-M. Deom $(\bowtie) \cdot$ R. Sala

Laboratory of Geoarchaeology, Al-Farabi Kazakh National University KazNU, 71 Av. Al-Farabi, 050060 Almaty, Kazakhstan

e-mail: ispkz@yahoo.com

A. Laudisoit

Institute of Integrative Biology, University of Liverpool, Crown Street, Liverpool, UK

(C) The Author(s) 2019

L. E. Yang et al. (eds.), Socio-Environmental Dynamics along the Historical Silk Road, https://doi.org/10.1007/978-3-030-00728-7_4 


\subsection{Introduction}

The Silk Road is not just a system of transport routes but includes also a series of human communities distributed along a longitudinal geographic corridor across Eurasia. In this sense, the Ili valley integrates both aspects: it constituted an important segment of east-west interregional itineraries as well as the historical habitat of important human cultures. It is located at the junction between the transcontinental roads of traders and the meridional Central Asian mountain corridor traveled by mobile pastoralists.

During the initial phase of activity of the classical Silk Road (II BC), the Ili valley was a wealthy political center under the rule of the Saka tribes (Eastern Scythians). These peoples were practicing pastoral vertical transhumances, had a mighty military power and were managing a lucrative horse trade with adjacent settled civilizations. Their importance, attested not only by Chinese accounts but also by the density and size of their funerary monuments (kurgans), which are among the largest in all Eurasia, witness the highly favorable ecological conditions of the region (Deom and Sala 2012; Gass 2016). The foothills of Semirechie enjoy a temperate climate with regular precipitations coming from the Atlantic atmospheric circulation, well watered alluvial fans nourished by snowy peaks, large summer pastures in mountains and, at few $\mathrm{km}$ of distance, winter camps in desert: all conditions providing good pastoral resources using short vertical migrations.

This Iron Age economical system derived from a scheme already developed during the Bronze Age $^{1}$ and continued to the modern era. The residential pattern consisting of winter camps in semi-desert and desert zones, spring and fall dwellings in foothills, and summer camps in mountains meadows has been extensively documented by the Laboratory of Geoarchaeology during more than 20 years of surveys of these three landscape zones. Settlements and burial grounds of all historical periods occupy the same loci in cultural layers overlapped or next to each other. Concerning the Ili delta, the fact that this territory has been used for millennia as a huge winter camp was not known until recently. Up to now the first and only recorded traces of human colonization of the delta consists of a line of medieval forts marking a caravan road.

The present article communicates for the first time the history of the human colonization of the Ili delta region. It begins with background knowledge about the geography and geological history of the territory (part 1) and about the former archaeological studies and ethnographical reports concerning the cultural processes that happened in the delta region and beyond its borders (part 2). Areas, methods and results of the present research are expounded in part 3. Part 4 provides the preliminary reconstruction of the complex interaction of natural and cultural processes that characterized during the last 4500 years the area of the third and second last deltas of the Ili river.

\footnotetext{
${ }^{1}$ By Bronze Age and its partitions in early, middle, late and final, we refer to their establishment on the Kazakhstan territory between 2800 and 800 BC.
} 


\subsection{The Ili Delta}

\subsubsection{General Features}

The Ili river system rises in Xinjiang and, fed by sources in China and Kazakhstan, develops for $1400 \mathrm{~km}$ forming a delta in the Southern Pre-Balkhash region, supplying $70 \%$ of the annual inflow to the Balkhash lake.

The last $300 \mathrm{ka}$ saw the succession of 5 generations of Ili river deltas. Under the forcing of sedimentary and tectonic processes, their heads and fronts were gradually displaced northwest and rotated anticlockwise, up to the present Balkhash shore, with their areas reducing in size and largely overlapping each other. In chronological order: (1) Akdala, (2) Bakbakty, (3) Uzunaral, (4) Bakanas, (5) Modern Ili.

Today relict and active channels stretch northwestward for $230 \mathrm{~km}$, starting at the foot of the Tasmuryn mountains at $415 \mathrm{~m}$ asl and ending in the Balkhash lake at $341 \mathrm{~m}$ asl, with an average slope of $0.30 \%$. The entire territory is clearly composed of 3 very different parts, western, central and eastern: the first consists of the area of the modern delta and the other two of the previous 4 deltas.

The western part, crossed by the active delta distributaries of the modern delta (modern Ili, Topar, Zhideli), is a vegetated wetland of $8000 \mathrm{~km}^{2}$, covered by tugai forest and reeds. The central part, which is 3 times wider than the first and includes the research area, contains the previous Bakanas and Uzunaral deltas and is today desiccated, covered by sand dunes with bushes and shrubs and cut by dry river channels with rare seasonally moistened segments. Here the most remarkable paleocourses, from west to east, are: the entire Naryn course and the mid-low Orta-Bakanas, which belonged to the second last Bakanas delta; and the upper Orta-Bakanas, the ShettBakanas, Ortasu and Akdala, which had been distributaries of the Uzunaral delta and, in segments of their upper course, expose rare traces of erosion by the other two most ancient deltas. The eastern part is the largest, developing further eastwards for more than $300 \mathrm{~km}$ until the Karatal river course. It consists of the most arid expanses of the huge Saryesyk-Atyrau desert, which constitutes the area occupied by the oldest Akdala and Bakbakty deltas, today totally invisible under a thick cover of aeolian deposits (Fig. 4.1).

\subsubsection{Geological History}

The geological history of the Ili delta as reconstructed by Soviet scientists provides the general background of the recent researches implemented in the region (Aubekerov et al. 2009; Dzhurkashev 1972; Sala et al. 2016).

Its establishment is dated around $300 \mathrm{ka} \mathrm{BP}$ when the Ili river was diverted northward by the uplifting of the Karoi plateau and started discharging its waters in the Balkhash depression, establishing a system of shallow lakes (Bakanas lake) that were progressively displaced northward by a huge accumulation of sediments (Kostenko 1978; Platonov 1959). 


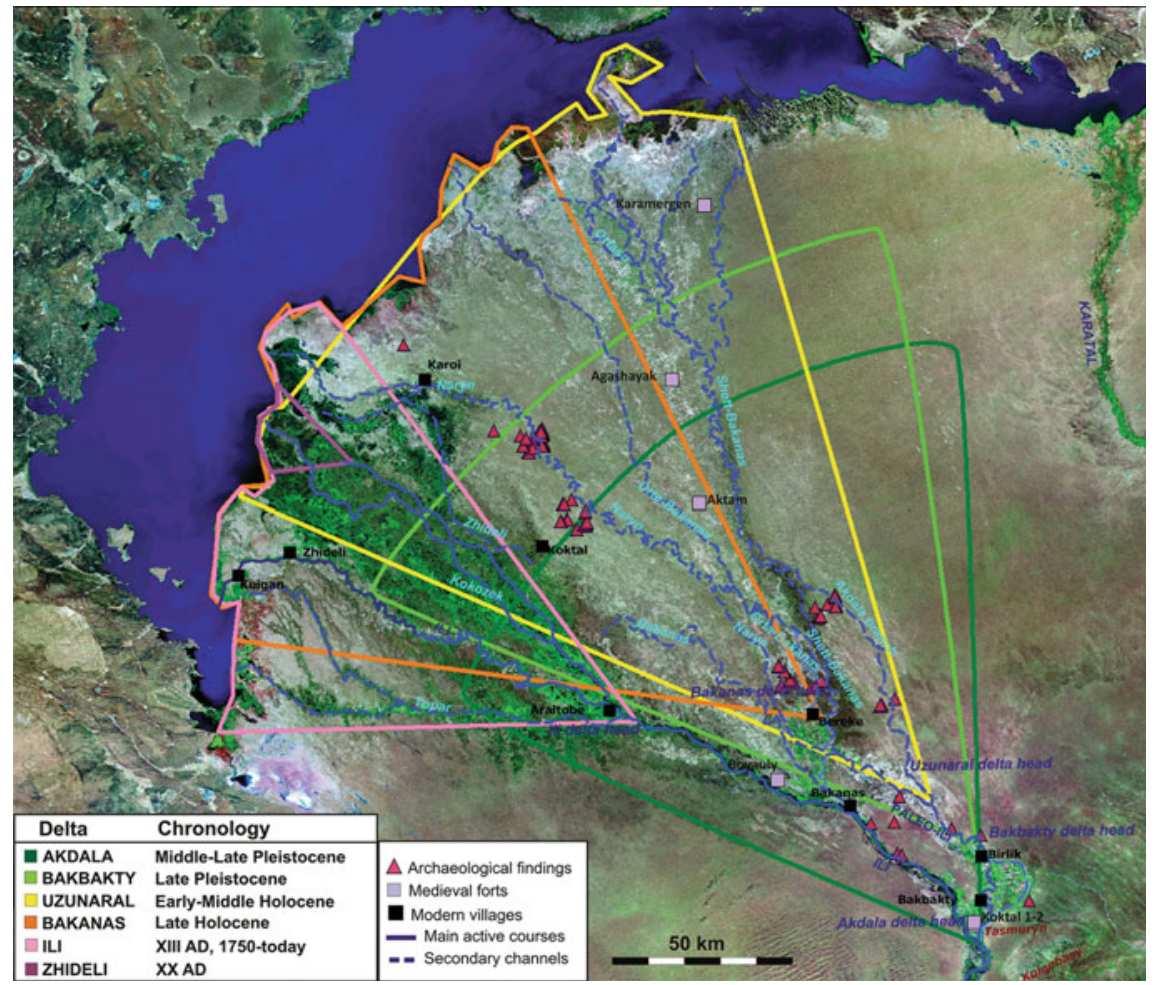

Fig. 4.1 Map of the Ili delta, showing the chronological succession of 5 main deltas and the location of camps and medieval forts. Adapted from Abdrasilov (1993), superimposed on Landsat image

Its subsequent evolution has been a quite complex process across a succession of several deltas. Arid phases, through diminishing the water regimes of delta distributaries, favor the erosion and lowering of the river channels, the formation of terraces and, generally, the stabilization of the existing delta morphology. The establishment of a new delta typically coincides with pluvial phases that enhance the energy levels of the river and promote diversions in various directions. Tectonic and sedimentary processes fix the thresholds that bring to sudden morphological changes and are responsible for the general patterns of the multi-millennial evolution.

Aeolian deposits of different thickness cover most of the region (with the exception of areas like floodplains and proluvia from where they are regularly washed away) so that the dating of their bottom layer by OSL can sort the chronological attribution of the covered surface.

An approximated reconstruction of the area and historical succession of deltaic fans has been produced by Abdrasilov (1993) (Fig. 4.1). For presenting our research, we will draw on this chronology, supplemented with fresh data collected during subsequent research projects (see below Sect. 4.1). 
The 300 ky long evolution of the Ili delta can be outlined in 5 phases, in chronological order: (1) Akdala, (2) Bakbakty, (3) Uzunaral, (4) Bakanas, (5) Modern Ili. The heads of the first two deltas were located at the outlet from the mountains and fed by a river segment called Paleo-Ili running on the plain for $10-50 \mathrm{~km}$. During the Middle Holocene, the third delta was formed: the head displaced $30 \mathrm{~km} \mathrm{NW}$, its distributaries slightly redirected anticlockwise, and their terminal sediments reaching the line of the present Balkhash shore and building the Saryesik peninsula.

During the Late Holocene, northward and anticlockwise displacements accelerated and the modern Ili river course became established, bifurcating from the Paleo-Ili at the mountain outlet and running parallel southwest of it. At first it proceeded just $50 \mathrm{~km} \mathrm{NW}$ until the area of the Bakanas village where it formed the fourth delta, the Bakanas delta: smaller than the previous ones and discharging totally in the Western Balkhash basin. During the last 700 years, the modern Ili opened its way $50 \mathrm{~km}$ further NW where the head of the modern Ili delta - the smallest - is located (Fig. 4.1).

1. Akdala delta (second half of Middle Pleistocene, 300-18 ka BP) is the most ancient. It was a large delta with head at the first outlet from the mountains (Tasmuryn) and distributaries running to NNE and spanning from west of the modern Ili course to the Karatal river course. Today its remains are covered by subsequent aeolian and alluvial sediments and are just barely detectable in the delta head zone. ${ }^{2}$

2. Bakbakty delta (Late Pleistocene, 18-8 ka BP). Following the late-glacial reduction of the Balkhash water surface and increased sedimentary processes, the Ili delta migrated $40 \mathrm{~km}$ north in the form of the Bakbakty delta. Fed by the Paleo-Ili course, its head was in the Bakbakty region; its distributaries, tectonically forced into anticlockwise rotation, ran to NNW; its front, more advanced, dammed the middle part of the Balkhash lake until $40 \mathrm{~km}$ south of the present shore.

3. Uzunaral delta (Early-Middle Holocene, 8-4 ka BP), also called Older Bakanas delta, was formed with the first significant moistening of climate occurring at the start of the Atlantic period. The delta head was displaced $30 \mathrm{~km} \mathrm{NW}$, half way to the Bakanas village; its distributaries (Uzunaral, Ortasu) ran NNW, its final deposits pushed the lake's coast further north to the modern shores. In that way the Saryesik peninsula has been formed, lying on $100 \mathrm{~m}$ thick sediments and separating the $\mathrm{W}$ and $\mathrm{E}$ Balkhash by the narrow and shallow Uzunaral strait, which is today $5 \mathrm{~km}$ wide and $5 \mathrm{~m}$ deep. An alternation of dry and pluvial phases marks the transition from the Middle to the Late Holocene, during which the Ili branches cut new narrower beds and wandered to the west of the Uzunaral strait, where in a couple of millennia a new delta was formed. ${ }^{3}$

\footnotetext{
${ }^{2}$ Preliminary results of OSL dating of terraces located at the head of the Akdala, Uzunaral and Bakanas deltas confirm the channel chronology given in the text and, in the case of Bakanas terraces, antecede the dating of diagnostic Bronze Age sherds. Anyhow, OSL dates are still under study and the final results will be published by Japanese geologists (Sato et al. 2013; Shimizu et al. 2012; Shimizu et al. 2015).
}

${ }^{3}$ See note 2 . 
4. Bakanas delta (Late Holocene, 4-0.3 ka BP), also called Younger Bakanas, is superposed to the wider Uzunaral delta, fed by a new parallel southern segment of the Ili course (New-Ili) and of lesser extension. The head is now located $30 \mathrm{~km} \mathrm{NW}$ and all its distributaries, today desiccated, were redirected to the NW discharging their waters in the Western Balkhash basin. According to the Soviet scientists who researched the soil stratigraphy and geomorphological profile of the Bakanas delta (Dzhurkashev 1972; Rybin 1955; Vyatkin 1948), in spite of the anticlockwise rotation of the delta system, the chronological sequence of the main branches of the Bakanas delta went from West to East, from Naryn (oldest and most eroded) to Orta-Bakanas and Shett-Bakanas (which takes active part in 3 successive deltas). Ruins of medieval towns and artificial canals attributed to the VIII-XIII centuries AD are aligned along the Shett-Bakanas and Ortasu distributaries, witnessing some persisting activities of these easternmost courses. ${ }^{4}$

5. Ili delta (700-250 BP-now). The switching from the Bakanas to the modern Ili delta happened very gradually during the XIII-XVIII centuries AD, a phase of relative humidity that followed the intense aridity of the Medieval Warm Period (Chiba et al. 2016). At first, a transitional "Bakanas" distributary oriented to the west was activated; then the entire water flow became concentrated in the Ili course that opened its way $50 \mathrm{~km}$ further NW towards Araltobe village, establishing here the head of the modern Ili delta. After a few centuries of double course activity and reversals, the Bakanas delta died off completely between the years 1733 and 1785 (Mushketov 1886). ${ }^{5}$ This last Ili delta has a muchreduced areal dimension beginning just $125 \mathrm{~km}$ far from the shore of the lake, and ramifies in few branches that chronologically succeeded each other from west to east: Topar, Iley, Zhideli.

\subsection{Archaeological Data and Ethnographic Accounts Concerning the Southern Balkhash Territory}

\subsubsection{Archaeological Complex}

The southern Balkhash region hosts monuments of all epochs, spanning from the Late Paleolithic to the modern periods (Deom et al. 2009). In particular, in the areas of the delta and in its immediate surroundings, archeological reports preceding the present communication documented the presence of the following monuments.

Late Paleolithic and Neolithic stone tools have been documented in 13 loci of the ancient shorelines of the Northern Balkhash and of the Ulken-Araltobe island (Dzhurkashev 1972), and on both sides of the Ili canyon upstream from the delta and

\footnotetext{
${ }^{4}$ See note 2 .

${ }^{5}$ According to the Russian geologist Mushketov, the Bakanas delta dried up between the years 1733 and 1785 as on the Oirat maps preceding this period, the Ili river was drawn with a large branch reaching the Bakanas.
} 
below the Kapchagai dam. No material clearly attributable to the Neolithic period or earlier has been found in the delta (Coque et al. 2000). In the western terraces of the Karatal river finds of Neolithic potteries (which are rare in Semirechie), grinding stone and pestle, lithics (including microliths, blades, scrapers, borers) have been reported (Arkheologicheskaya karta 1960); however, according to the description of the finds, these collections include also ornamented sherds and Bronze objects that seem more related to the Early-Middle Bronze Age.

Bronze Age copper slag and potsherds have been found in all areas spoken above. These sites could belong to the earliest phase of the Bronze Age in the region. Ascribed to this phase are settlement layers dated to the Chalcolithic-Early Bronze in the foothills of the Tienshan, like the pit house floor found in the Talgar fan (3360-3100 cal. BC) (Macklin et al. 2015), and in the upland valleys of the Djungarian Alatau, like the cist burial in Tasbas (2832 and 2492 cal BC) (Doumani 2014).

Contra the formerly accepted view that in Semirechie the Bronze age started in the early II millennium BC with the coming of Andronovo tribes from Central and East Kazakhstan, recent excavations in the Djungarian Alatau (Begash, Tasbas, Dali) and a new campaign of absolute dating of materials resumed from the Zailiski Alatau (Turgen, Kyzylbulak) pushes the chronology of the colonization of the region to the XXV century BC, i.e. the Early Bronze Age (Frachetti et al. 2014; Gass and Goryachev 2016).

Petroglyphs starting from the Bronze Age are present above the delta head in the last small mountain ranges of Kulanbasy and Tasmuryn. Typical Bronze Age cist tombs are found on the northern shore of the Balkhash and on the Tasaral island.

Iron Age kurgans are located on the terraces of the modern Ili course (Marikovskii 1982) and along some paleo-channels at the south of Bakbakty village. No kurgans have been documented further downstream neither in the Bakanas delta.

The Medieval period is represented by 8 square forts (tortkuls) that have been studied during 4 expeditions (1962-1997) and dated between VIII-XIII centuries AD, from south to north: Koktal 1 and 2, Boyauly, Aktam, Karkaraly, Agashayak, Karamergen and Barkhan (Akishev and Baipakov 1969; Baipakov and Groshev 1993; Baipakov 1998; Baipakov et al. 2001). Karkaraly and Barkhan ${ }^{6}$ have been barely identified during 2 different expeditions just on the base of potsherds and slag accumulation, and both lack dimension and precise location. The other 6 had been documented in plan and can be considered as real monuments: Koktal 1-2 and Boyauly are now under rice fields or village houses; Aktam, Agashayak and Karamergen are still visible aligned along the Shet-Bakanas paleocourse (Fig. 4.1).

Around Aktam the ruins of 'settled agrarian cultures' were reported on the basis of numerous potsherds, dated at first to the VII-IX centuries AD and ascribed by later publications to the X-XIII centuries AD. The presence of a copper melting workshop has been suspected on the basis of copper slag and fragments of copper vessels. Also SW and W of Aktam, near the Orta-Bakanas course, medieval houses

\footnotetext{
${ }^{6}$ Concerning Barkhan, a dense deposit of potsherds along a takyr, without visible structures, only makes the presence of ruined 'houses' suspect.
} 
and other pottery and metallurgy workshops have been recorded, stretching for $7 \mathrm{~km}$ along the main and secondary canals.

In the surrounds of the 3 visible medieval forts, remains initially interpreted as complex irrigation networks consisting of one magistral canal and several secondary channels, sometimes extending for few $\mathrm{km}$ till the banks of a main delta branches (from Aktam till Orta-Bakanas, from Agashayak and Karamergen till Shett-Bakanas) have been reported as well as associated to irrigated agricultural fields with identifiable planimetry, supposedly corresponding to the cultivation of 'cucurbitaceae and vineyards'. In 1997 an expedition especially devoted to the pedological assessment of phases of activity of the forts contradicted those hypotheses, revealing that forts were built in a dry environment when no active channels were crossing the area and that the ruins interpreted as 'irrigation systems' were just small aryks (water ditches) using natural paleochannels for bringing water till the forts.

Late Medieval (Ethnographic) period. During the Jungar khanate (1634-1745 $\mathrm{AD}$ ), the Oirat (Kalmyk) tribes intensively occupied Semirechie and the Ili delta, multiplying winter camps, organizing irrigated agriculture and building forts. They erected 3 walled garrisons in the estuary of the Zhideli branch, later partially eroded by floods, and others near the modern villages of Bakbakty and Bakanas. Most probably they also reused the 3 forts that are clearly visible along the Shett-Bakanas.

These data are supported by toponymic evidence. In the Zhidely estuary, a long stripe of sand dunes paralleling the river is called Ush-tam (meaning '3-mounds' or '3-forts') and was previously called Ush-kalmak (meaning '3-Kalmyk', i.e. Bas, Orta, Ayak, 'Upper, Middle, Lower') referring to 3 Kalmyk groups living in the area (Erofeeva 2008). According to the pedologist M. Vyatkin, the ancient irrigated fields found in areas with resurgent riverbeds (zabok) at the Bakanas delta head and in the middle Naryn course were initially built by Kalmyk tribes during the middle of the XVIII century AD (Vyatkin 1948). Kalmyk peoples were also living in the eastern parts of the delta, probably in the 3 medieval forts aligned along the Shet-Bakanas course. In fact, until the end of the XIX century AD, the fort Aktam was called Durtgut, which doesn't have any meaning in Kazakh and might refer to the 'Torghuts', a main Kalmyk tribe that settled in the Ili and then moved to the NW Caspian. The Russian geographer N. Palgov reported in 1930 that the Kazakhs considered the 3 'Aktam' (referring in this case to Aktam, Karamergen plus Boyauly or another fort north of it) as Kalmyk vestiges "haunted by ghosts" (Palgov 1932).

\subsubsection{Ethnographic Accounts}

Ethnographic accounts of Russian geographers provide important information on the land and water use within the delta during the XIX century and the start of the XX century.

Concerning ethnic distribution and land use, the driest parts of the delta (3/4 of it) were available for common use, while the relatively moistened lands closer to the Ili banks were belonging to Jalair tribes (Baigaly, Baichigir) from the Karatal valley. 
Most of the Jalair clans were living all year round in the delta, though the richest stockbreeders would practice seasonal migration between the best winter camps in the delta and summer pasture in the Djungarian Alatau (Aristov 1894; Vostrov and Mukanov 1968), with horses and camels, because sensitive to mosquitoes, gnats and botflies, all sent during summer to the highlands.

Concerning caravan routes across the delta, significant information was recorded by N. Palgov who carried out the population census of the region in 1930. According to his account, there were several caravan roads linking the Ili delta to the lower Karatal river, with raft ferries helping the cross of active delta branches. The main road, called Otrau-zhol (delta road) was following the right bank of the Ili river till modern Karoi village and then turning eastward along the southern shore of the Balkhash lake till the Karatal estuary. It was the most crowded due to the availability of water, it had several yurt villages regrouped around active wells. The second main road, shorter but much harder, called Tuya-kuduk-zhol (the road of the camel well), crossed the Bakanas delta in its central part through the ruins of Aktam and a series of often saline wells in a depopulated corridor. These tracks were also used for transporting salt collected in the salt pans on the right bank of the lower Karatal: it was considered the best culinary salt of South Kazakhstan and sold by Kazakh herders in Ushtobe, $100 \mathrm{~km}$ upstream, at the price, in 1942, of $1 \mathrm{~kg}$ of salt for $1.5 \mathrm{~kg}$ of wheat floor (Miller 2014).

It is also recorded that 500 yurts of the Argyn tribe living on the northern shores of the Balkhash lake were grazing in the Ili delta during winter by crossing the iced surface of the lake (Rumyantsev 1913). As soon as ice melted in spring, fishing became an important activity, an expedient surely in use during all epochs.

\subsection{Geoarchaeological Study and Chronological Attribution of the Human Occupation of the Ili Delta}

\subsubsection{Research Projects, Area and Methodology}

\subsubsection{Research Projects}

The background of the present research started with the Japanese-Kazakh project (2007-2012), based on the cooperation of 3 institutions ${ }^{7}$ and dedicated to the reconstruction of the Holocene environmental changes in the Ili-Balkhash basin. The project implemented studies of the evolution of environmental and cultural aspects of the Balkhash basin: climatic changes and lake water levels, shorelines, alluvial deposits, river terraces and sand dunes, archaeological traces of land-water use, reading of Late Medieval historical accounts and Soviet documents concerning

\footnotetext{
${ }^{7}$ The 3 institutions are: Research Institute for Humanity and Nature (RIHN), Kyoto; Laboratory of Geoarchaeology, Almaty; K.I. Satpaeva Institute of Geological Sciences, Almaty.
} 
the territory, interviews about post-Soviet pastoral and agricultural activities in the region, and geoarchaeological surveys with documentation and collection of surface archaeological material (Endo et al. 2012; Sala et al. 2016).

Geoarchaeological surveys were undertaken during 4 seasons (2008-2011) along the Balkhash lake shorelines, on the terraces of its tributary rivers (Ili, Lepsy), and in particular on terraces of Ili paleo-deltas. The fieldwork yielded the discovery of an unexpectedly abundant surface material representing a wide chronological frame from Eneolithic to modern times (Deom et al. 2012), giving impetus for further research.

Further work followed in 2011-2013 under the auspices of the British-Kazakh Wellcome Trust Project "Advances in the Prediction of Plague Outbreaks in Central Asia", aimed at studying the percolation of plague in gerbil population by mapping and analyzing their burrows in the area of the Ili delta (Wilschut et al. 2013). Together with the biologist Anne Laudisoit surveying rodents' colonies, we collected surface archaeological findings during 3 seasons.

\subsubsection{Study Area}

The survey areas represent the entire variety of desert habitats at varying distances from the piedmont zone. The upper parts of the entire delta system deserved special geological analyses intended for interpreting the chronological succession of the deltas. The Naryn paleocourse has been privileged as it represents the most relevant and longstanding active or intermittent course during the last 4000 years.

Geoarchaeological surveys focused on the river terraces distributed all along the entire course of the today dry Uzunaral and Bakanas paleodeltas (the area spoken as 'central' in Sect. 2.1), in particular: the terraces of the paleo-Ili and modern Ili river segments upstream from all deltas; the heads of the Bakbakty, Uzunaral and Bakanas deltas; the upper courses of the Akdala, Shett-Bakanas and Orta-Bakanas paleodistributaries; and the entire upper, middle and lower course of the Naryn paleodistributary.

As a whole, have been surveyed the terraces of 3 regions, focusing on 11 zones (Z-1-11) of $10 \times 10 \mathrm{~km}$ (marked in Fig. 4.2 and listed in Tables 4.1 and 4.2), where has been detected a total of 70 clusters (areas of $200 \times 200 \mathrm{~m}$ at mutual distance of $>200 \mathrm{~m}$ ) including a total of 134 loci (areas of around $20 \times 20 \mathrm{~m}$ characterized by a dense deposition of cultural objects). ${ }^{8}$

The eastern and northeastern borders of the Bakanas delta, at the location of the 4 medieval forts of Aktam, Agashayak, Karamergen and Barkhan, are not yet explored and should be the object of future research. Four archaeological expeditions devoted to the study of the forts and their hydraulic implementations have recorded the surface occurrence of a large numbers of potsherds (exclusively medieval, VIII-XIII

\footnotetext{
${ }^{8}$ Concerning the repartition of the survey areas between the Japanese-Kazakh and British-Kazakh projects, see Fig. 4.2. Regions, zones, clusters and loci are listed in Table 4.1. Of the total 134 loci, 39 have been found under the first project, 95 under the second.
} 


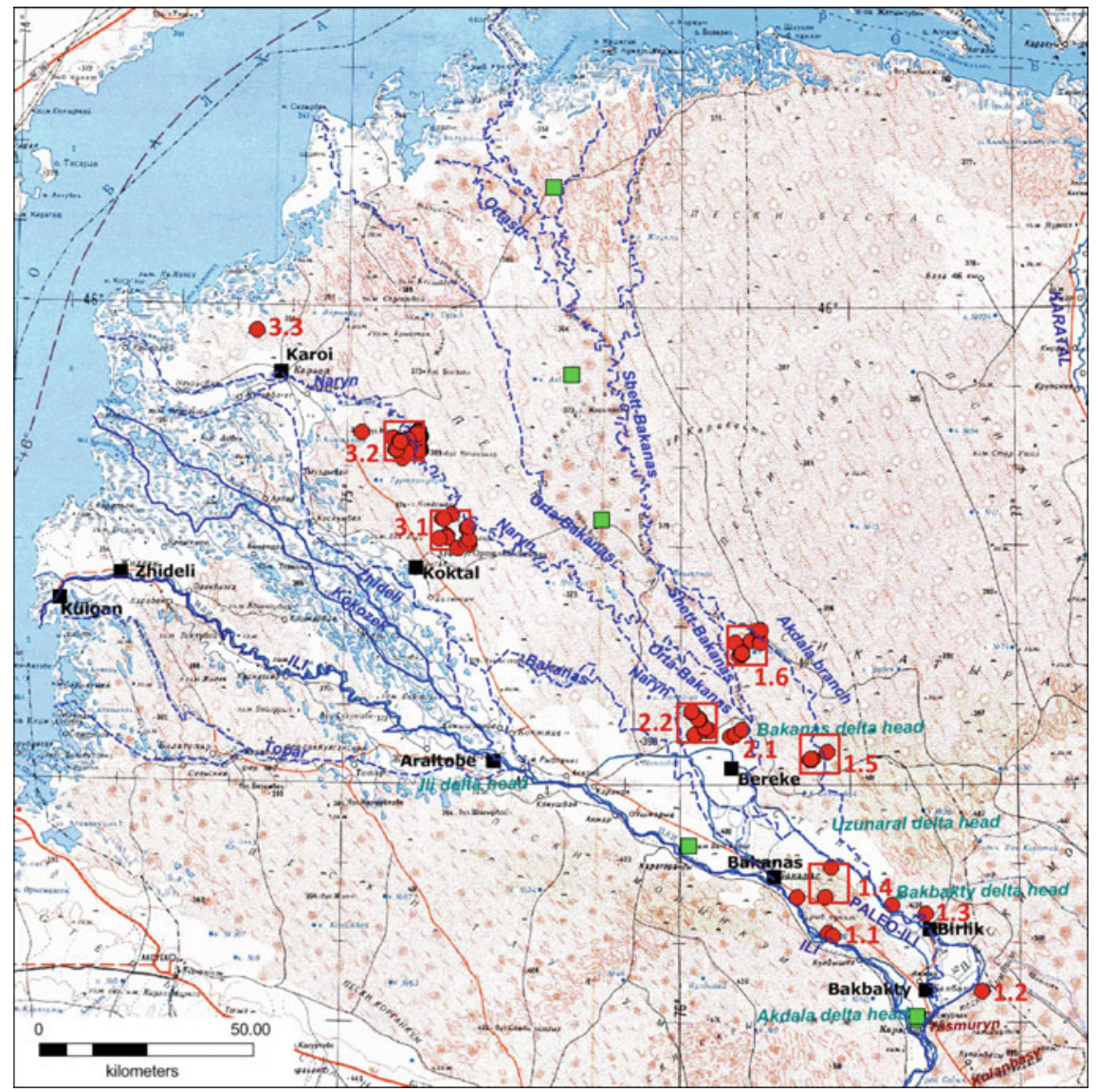

Fig. 4.2 Map of the researched territory. Red dots=loci of cultural findings; green squares $=$ medieval forts; square red perimeters of $10 \times 10 \mathrm{~km}=$ areas studied under the Wellcome Trust project. Zones are marked by red numbers. Paleo and modern paleo delta heads marked in azure. (Soviet topo map L-43, scale 1:1 million)

centuries $\mathrm{AD}$ ) scattered around the forts (sometimes within a radius of $7 \mathrm{~km}$ ) and also in northern areas closer to the Saryesyk peninsula (Baipakov et al. 2001).

\subsubsection{Methodology}

Methodological procedures have been chosen specifically for selecting surveying areas, collecting and analyzing artifacts, fixing a data base and elaborating data by statistical analyses.

Surveys Surveys were implemented through field walking for collection and GPS recording of surface finds. They didn't constitute a systematic grid-based survey 
Table 4.1 Ili paleodelta: assemblages of surface finds by zone, material and period

\begin{tabular}{|c|c|c|c|c|c|c|c|c|c|c|}
\hline \multicolumn{11}{|c|}{ Location and number of sites and finds (microlyths and sherds) } \\
\hline \multicolumn{4}{|c|}{ Location } & \multicolumn{7}{|c|}{ Finds } \\
\hline \multirow{3}{*}{ Region } & \multirow{3}{*}{ Zone } & \multirow{3}{*}{ 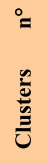 } & \multirow{3}{*}{$\begin{array}{l}\stackrel{0}{=} \\
\bar{\Xi} \\
\stackrel{\Xi}{J}\end{array}$} & \multirow{3}{*}{ 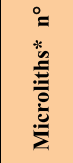 } & \multicolumn{6}{|c|}{ Sherds } \\
\hline & & & & & \multicolumn{2}{|c|}{ by Zone } & \multicolumn{4}{|c|}{ by Period* $n^{\circ}$} \\
\hline & & & & & $\mathbf{n}^{\circ}$ & $\% * *$ & B & EI & $\mathbf{M}$ & $\mathbf{K Z}$ \\
\hline \multirow{7}{*}{$\begin{array}{l}1 \\
\text { Akdala } \\
\text { head, } \\
\text { Bakbakty } \\
\text { head }\end{array}$} & 1.1- Ili upper, R-bank & 4 & 14 & 11 & 127 & 9.6 & 31 & 64 & 16 & 5 \\
\hline & 1.2- Akdala delta head & 1 & 2 & 0 & 8 & 0.6 & 8 & 0 & 0 & 0 \\
\hline & 1.3- Paleo-Ili (Birlik-N) & 2 & 6 & 11 & 38 & 2.9 & 9 & 11 & 6 & 1 \\
\hline & 1.4- Bakbakty delta head & 3 & 12 & 3 & 25 & 1.9 & 9 & 8 & 4 & 1 \\
\hline & 1.5- Akdala-mid & 5 & 6 & 9 & 16 & 1.2 & 1 & 1 & 0 & 5 \\
\hline & 1.6-Akdaka-low $\perp$ Shett B. upper & 12 & 13 & 33 & 132 & 10 & 34 & 54 & 11 & 0 \\
\hline & Subtotals & 27 & 53 & 67 & 346 & 26 & 92 & 138 & 37 & 12 \\
\hline \multirow{3}{*}{$\begin{array}{l}2 \\
\text { Bakanas } \\
\text { head }\end{array}$} & 2.1- Orta-B. upper & 4 & 7 & 0 & 18 & 1.4 & 3 & 10 & 4 & 1 \\
\hline & 2.2- Naryn upper & 6 & 7 & 3 & 57 & 4.3 & 21 & 18 & 10 & 5 \\
\hline & Subtotals & 10 & 14 & 3 & 75 & 5.7 & 24 & 28 & 14 & 6 \\
\hline \multirow{4}{*}{$\begin{array}{l}3 \\
\text { Naryn } \\
\text { mid-low }\end{array}$} & 3.1- Naryn mid & 10 & 20 & 5 & 331 & 25 & 190 & 107 & 29 & 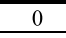 \\
\hline & 3.2- Naryn low & 21 & 45 & 0 & 550 & 41.6 & 287 & 191 & 72 & 0 \\
\hline & 3.3- Naryn final & 2 & 2 & 0 & 18 & 1.4 & 1 & 6 & 11 & 0 \\
\hline & Subtotals & 33 & 67 & 5 & 899 & 68.1 & 478 & 304 & 112 & 0 \\
\hline TOTALS & zones: 11 & 70 & 134 & 75 & 1245 & $100 \%$ & 594 & 470 & 163 & 18 \\
\hline \multicolumn{4}{|c|}{ Ratio on total $n^{\circ}$ of sherds and microliths (1320) } & $(5.6 \%)$ & \multicolumn{2}{|c|}{94.3} & $(45 \%)$ & (35.65) & (12.3) & $(1.3 \%)$ \\
\hline
\end{tabular}

* $\quad \mathrm{Mc}=$ Microliths (19\% Pre-Bronze, $81 \%$ Bronze), B=Bronze Age, EI=Early Iron, M=Middle Ages, KZ=Kazakh (Ethnographic) period (last 4 centuries).

** The ratio of finds by zone is calculated on the total number of finds in all zones. Highlights are applied to numbers relatively high by column: azure=very-high, green=high, yellow=average.

aimed at geostatistical analyses, as it has been done fruitfully in other paleodeltas of arid Central Asia (Markofsky 2014) but focused on the terraces of dry paleodelta channels.

Spatial Selection In the frame of the first research project 2007-2012, the strategy of survey was motivated by the aim of gathering chronologically attributed artefacts on terraces of paleochannels where geomorphological profile and sampling for absolute dating were also implemented, in order to correlate geological and cultural chronologies. In this context, the surface collection was done in a perimeter of $1 \mathrm{~km}$ around the study site.

The spatial objective of the second project was circumscribed to selected square areas with good satellite image resolution and high density of rodent burrows, which happen to correspond to the areas crossed by the main and most ancient segments of paleodeltas. For plague monitoring, the research area was based on a cartographic division of the territory into primary squares $(40 \mathrm{~km} \times 40 \mathrm{~km})$, then each into four 
Table 4.2 Ili paleodelta: Assemblage of surface finds by zone, material, period and diagnostic type

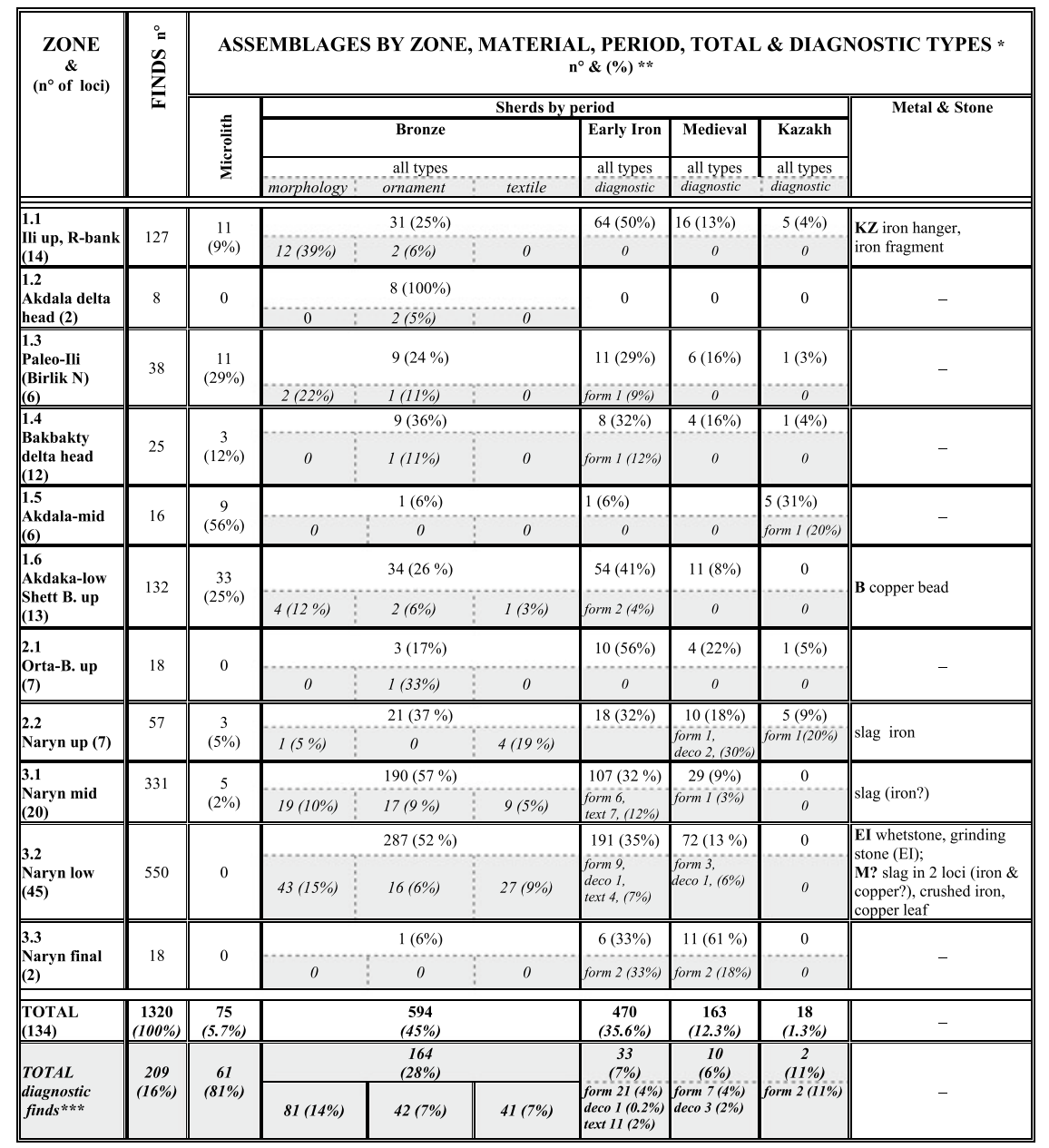

* Materials: microlith, sherd, metal, stone. Periods: B=Bronze, EI=Early Iron, M=Medieval, KZ=Kazakh. Diagnostic sherds of 3 types, by: morphology, ornament, textile imprints (rows marked in grey).

** For each zone, the ratio of $n^{\circ}$ of sherds of all types is calculated on the $n^{\circ}$ of sherds of all periods within the same zonal assemblage; the ratio of $n^{\circ}$ of diagnostic sherds is calculated on the $n^{\circ}$ of all sherds of the same period within the same zonal assemblage.

*** The ratio of total diagnostic finds is calculated on the above total number of finds.

${ }^{a}$ Materials: microlith, sherd, metal, stone. Periods: $B$ Bronze, EI Early iron, $M$ Medieval, KZ Kazakh. Diagnostic sherds of 3 types, by: morphology, ornament, textile imprints (rows marked in grey)

${ }^{b}$ For each zone, the ratio of $n^{\circ}$ of sherds of all types is calculated on the $n^{\circ}$ of sherds of all periods within the same zonal assemblage; the ratio of $n^{\circ}$ of diagnostic sherds is calculated on the $n^{\circ}$ of all sherds of the same period within the same zonal assemblage

${ }^{\mathrm{c}}$ The ratio of total diagnostic finds is calculated on the above total number of finds 
secondary squares $(20 \mathrm{~km} \times 20 \mathrm{~km})$ and these into four sectors $(10 \mathrm{~km} \times 10 \mathrm{~km})$, as described elsewhere (Wilschut et al. 2013). The study sites concerned randomly chosen $500 \mathrm{~m} \times 500 \mathrm{~m}$ (25 ha) squares spread over 6 sectors (see Fig. 4.2) (Levick et al. 2015).

In the context of these sectors, within 3 seasons (autumn 2011, summer and autumn 2012, spring 2013), 2113 burrow were mapped and most of the surface artefacts were collected. Other finds were gathered when circulating on foot between close squares (within $10 \mathrm{~km}$ radius) and during a recognizance survey in the estuary of the Naryn channel. Visual contact with surface archaeological remains occurred predominantly on the ledge of recently dug burrows, around takyr, between dunes, and along the banks of dry paleodelta channels (Photo 4.1).

Collection and Count In each spot with single or multiple finds, the total or a representative amount of archaeological items was collected. Potsherds are by far the most abundant finds, so that in loci with numerous finds, the ones belonging to the same pot and similar sherds were discarded. Among other artefacts, microliths slag, metals and stone tools were systematically collected. Surface finds visually contacted were photographed, georeferenced and packed in labeled bags.

All data were recorded in a database, which includes several entries: exact location, geomorphological setting, amount and type of findings, preliminary chronological attribution, and assessment of buried condition (uplifted, deposited). Subsequent office work based on satellite images added new entries such as elevation and proximity to stream.

Loci and Terraces Most of the loci discovered during the surveys-86 out of the total $134(64 \%)$ - are located on relict or active river terraces, allowing the chronological correlation between cultural and geological data sets. The spatial distribution of the loci corresponds to the orientation of the delta channels and of the dune ridges associated with them, both having, as the dominant wind in the delta, a NNW-SSE direction.

They all consist of surface finds without stratigraphy and are not associated with visible settlement structures or irrigated fields. Most of the surface scatters probably correspond to the original location of occupied sites, but many are located around takyr depression as aggregation from surrounding dunes. Actually, it is almost impossible to distinguish surface and subsurface material being that most of the artefacts might have moved with dune displacement and been uplifted by rodents.

The entire territory of the delta is densely populated by the great gerbil (Rhombomys opimus, carrier of endemic plague), which builds burrows with galleries usually running $30-50 \mathrm{~cm}$ below the surface while food and nest chambers can be built as low as $5 \mathrm{~m}$ underground (average $2.5 \mathrm{~m}$ ). By digging and cleaning, the rodents constantly excavate and eject to the surface ancient objects, stones, pebbles, vegetation debris, bones and faeces. This is how most of the findings were spotted. 
Chronological Attribution of the Surface Material The non-stratified, open site condition of the surface artifacts discourage the possibility of the absolute dating of finds, leaving the chronological information to be retrieved from their typological elements. Out of total 1331 finds, 1320 have been chosen for chronological attribution (Table 4.1).

Sherds have been first of all visually classified according to: (1) shape and thickness; (2) technique of manufacture and firing, hand or wheel made, external and internal color, etc.; (3) paste and inclusions. These elements allow their preliminary partition within 4 periods (Bronze, Early Iron, Medieval and Kazakh-Ethnographic periods). The resulting chronological classification allows the implementation of statistical analyses (see below), at the cost of few ambiguities and potential mistakes. ${ }^{9}$

A way to increase chronological confidence exists: it consists in sorting among the entire bulk of sherds and microliths just the diagnostic samples carrying more precise chronological markers. Diagnostic sherds (16\% of their total) are individuated by 3 types of markers: morphological elements (rim, base, spout, handle, etc.), ornaments (incised, applied or colored), and textile imprint (molding technique) (Photo 4.2). The most reliable for chronological attribution are diagnostic sherds with decoration (typical); slightly less reliable are those carrying shape and/or fabric (textile) information. Diagnostic microliths (81\% of their total) are individuated by presenting forms classified as characteristic of the Bronze period in several stratified sites of Semirechie.

A disadvantage of this procedure is the reduction of reference samples to $16 \%$ and their specific distribution within sites and periods, i.e.: some loci would be empty and disappear from the count and ornamental proclivities would privilege the Bronze period (where diagnostic sherds constitute the $28 \%$ of the total) and disfavor the others (Iron Age 7\%, Medieval 6\%, Kazakh 11\%) (see Table 4.2).

On the other side an advantage of referring to diagnostic artefacts is that in some cases they can provide better temporal resolution. This happens for the diagnostics of the Bronze Age pointing to sub-periods and, by being predominantly dated to the Late or Final Bronze, indicates those phases as the ones concerned by largest wave of Bronze Age colonization of the delta.

Assemblages by Loci and Periods The statistical analysis of the ratio of chronological assemblages by zone and period provides precious information about the privileged human habitats during particular phases, under different climate, hydrological regimes and socio-economical scenarios.

In general, zonal and local assemblages include artifacts of different periods and in different ratios, but some sites are characterized by a dominant chronological assemblage representing $\geq 50 \%$ of the total finds. 6 out of 11 zones follow that category:

\footnotetext{
${ }^{9}$ For decreasing potential arbitrary attribution, the chronology of collected artifacts was crosschecked by A. Goryachev and K. Dubyagin, archaeologists of the Margulan Institute of Archaeology of Almaty.
} 

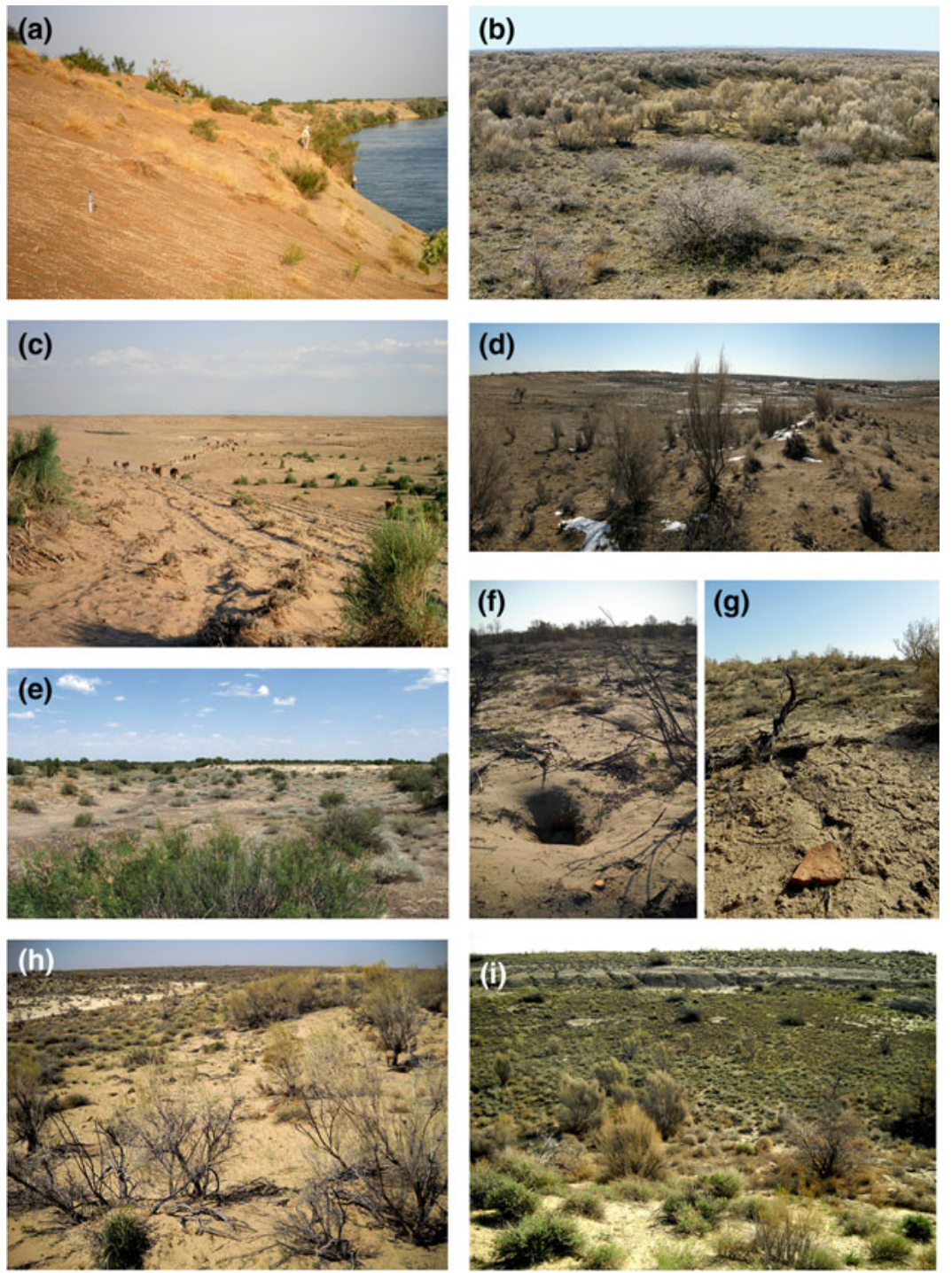

Photo 4.1 View of loci with surface finds in 6 zones representative of the Ili paleo-delta system. a Right terrace of the modern Ili river (Z-1.1); b Akdala delta head (Z-1.2); $\mathbf{c}$ Paleo-Ili relict course at Birlik-N (Z-1.3); d Bakbakty delta head (Z-1.4); e Bakanas delta head in the upper Orta Bakanas (Z-2.1); f surface sherd uplifted by great gerbil from burrow; $\mathbf{g}$ surface sherd at the border of takyr depression; $\mathbf{h}$ dune ridge stretching NW-SE vegetated by saxaul trees in the Naryn branch (Z-3.1); i dry bed of the Naryn paleocourse seen from its western terrace (Z-3.1) 
- the Bronze period assemblage is dominant by $100 \%$ in the Akdala delta head (Z-1.2), by $57 \%$ in mid-Naryn paleo-course (Z-3.1) and by $52 \%$ in low Naryn (Z-3.2).

- the Early Iron assemblage is dominant by $50 \%$ on the right bank of the upper Ili course (Z-1.1) and by 56\% in the upper Orta Bakanas (Z-2.1).

- the Medieval assemblage is dominant in final Naryn (Z-3.3) (Table 4.2).

Quite interesting is the distribution of microliths, which can refer to the PreBronze or Bronze periods. They are mainly found in the upper part of the delta system: the highest number of Pre-Bronze types (11) along the Upper-Ili course (Z$1.1)$; Bronze types in the Mid-Akadala (Z-1.5) where 9 pieces represent $59 \%$ of the local assemblage, and in the Low-Akadala (Z-1.6) where 33 pieces represent $25 \%$.

\subsubsection{Research Results}

\subsubsection{Spatial Distribution and Density of Finds}

Concerning the number of cultural findings by region, the densest is by far the Narynmid-low region including almost half of the total documented loci and more than half of all finds. In general the loci of the middle and lower delta system are more concentrated and include more finds than the loci at the delta heads.

\subsubsection{Classification of Findings by Type, Area and Chronology}

99\% of all finds (1331) consist of potsherds [1245 (93.5\%)] and stone tools (microliths) [75 (5.6\%)]: together they count 1320 pieces providing the data base for statistical analyses. The remaining 11 pieces $(1 \%)$ consist of iron and copper slag (along the Naryn), metal objects (copper bead, copper leaf, iron hanger, crushed iron), and grinder and whetstone (probably Iron Age), adding some qualitative information (Fig. 4.3).

The chronology of the inventoried material spans from Eneolithic (turn of the IV to III millennium BC) to the ethnographic period (200 BP), evidencing the use of the full extent of the delta from the earliest periods. The most numerous are samples attributed to the Bronze Age (45\% of total finds), followed by Early Iron (36\%), Medieval (12\%), Ethnographic (1\%). Tables 4.1 and 4.2 present the systematization of all collected data by zone and period.

\section{Microliths}

Most of the lithic material consists of small cores, tools (blades, scrapers, notches, knives) and spalls made of chalcedony, agate, flint, jasper and fossil wood. Lacking laminar and geometrical forms typical of the Neolithic, they could be attributed to both the Eneolithic and Bronze periods, being that in Semirechie and Central Kazakhstan such items are commonly found in the cultural layers and surface sur- 


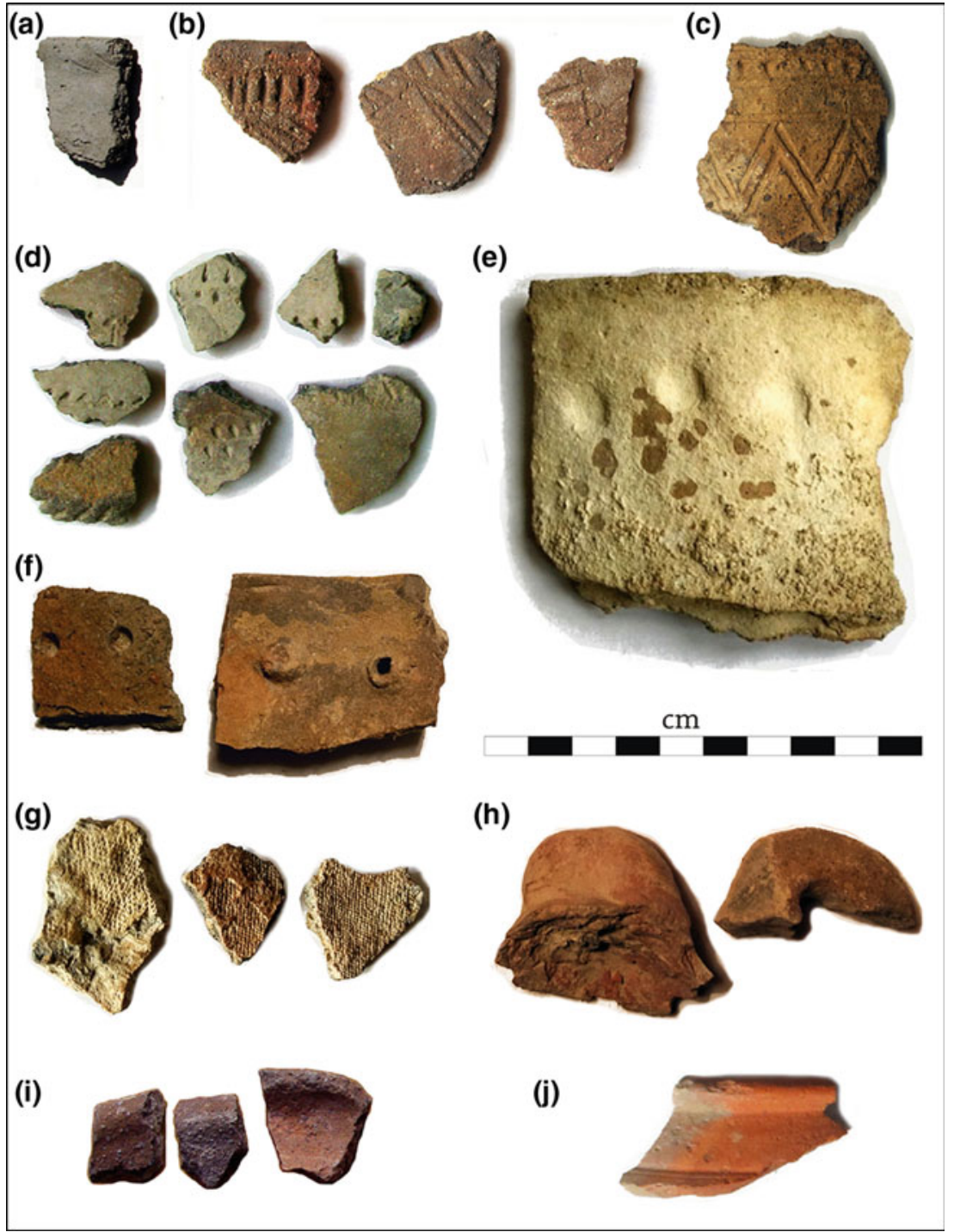

Photo 4.2 Diagnostic sherds. a-e Mid-Late Bronze Age ornamented sherds (a-Paleo-Ili Z-1.3, b-Naryn-mid Z-3.1, c-Naryn-mid Z-3.1, d-Mid-Naryn-mid Z-3.1, e-Ili upper right bank Z1.1), $\mathbf{f}$ final Bronze applied 'pearl' ornament (Naryn-low Z-3.2), $\mathbf{g}$ bronze Age with textile mold imprint (Naryn-low Z-3.2), $\mathbf{h}$ iron age tabbed and disk-shaped lug handles (Naryn-low Z-3.2), i medieval rims and bottom (Naryn-mid Z-3.1), j ethnographic neck (Naryn-upper Z-2.2) 


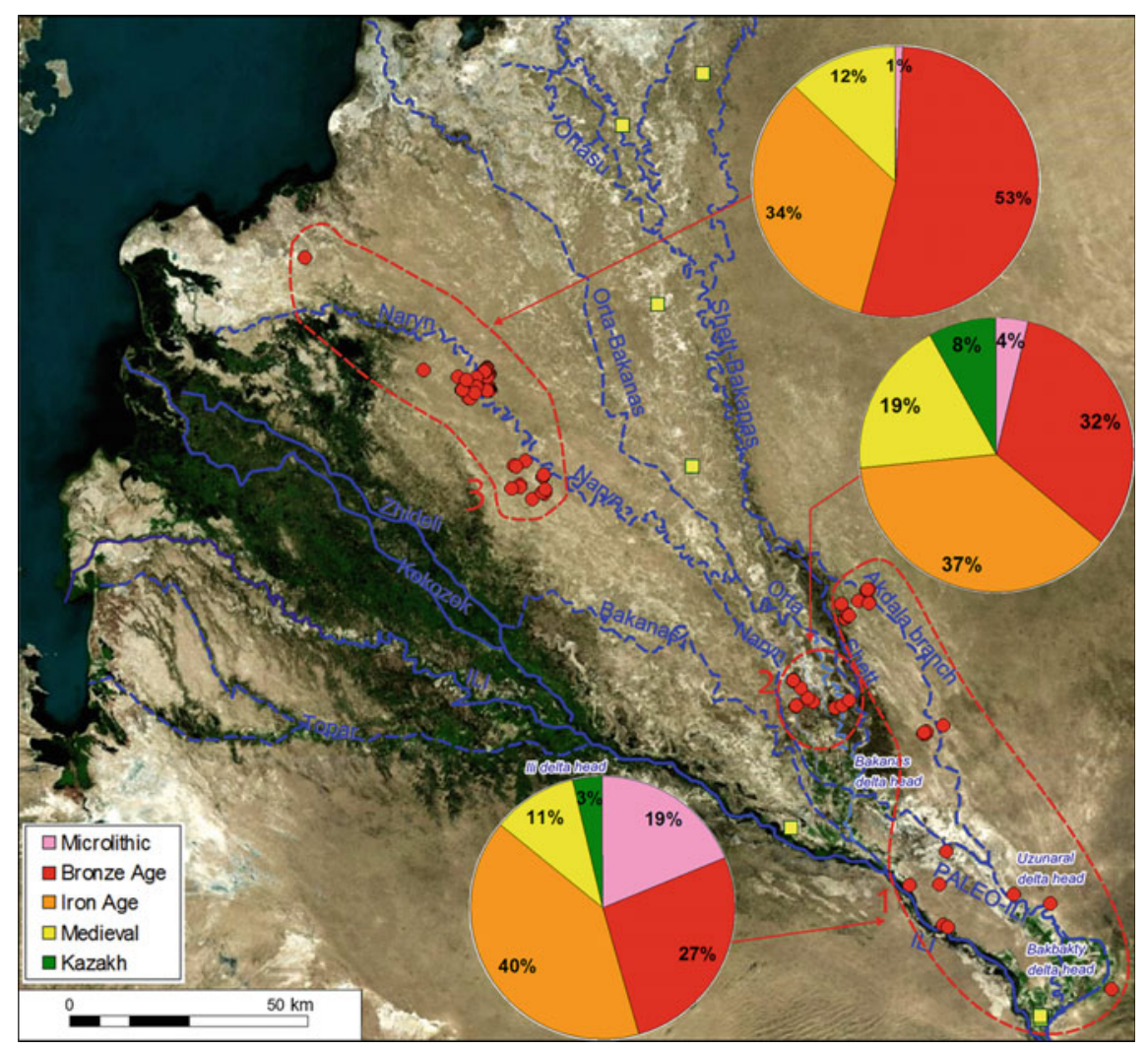

Fig. 4.3 Map and chronological distribution of findings by region (Bing map, 2011)

roundings of Bronze Age settlements. ${ }^{10}$ A $20 \%$ of roughly flaked tools, some made of porphyry, collected on the right terraces of the modern Ili river, could belong to a pre-Bronze period. ${ }^{11}$

Microliths have been found in all regions, with highest occurrence in the upper parts of the paleo-deltas, nearer to the mountains: in the Akdala and Bakbakty delta heads $(\mathrm{Z}-1.2,1.4)$ (44\% of the microlithic collection), on the terraces of the Paleo-Ili in Birlik (Z-1.3) (15\%), and in the very dry mid-Akdala branch (Z-1.5) where they constitute up to $56 \%$ of the zonal assemblage.

\footnotetext{
${ }^{10}$ The presence of microliths according to some authors is associated with pre- and early Bronze Age layers and disappears with the second millennium BC; but, according to others, it continues till the end of the Final Bronze Age (A. Goryachev, personal communication).

${ }^{11}$ Stone tools made of porphyry are characteristic of the Upper Paleolithic sites of the Tienshan foothills like Maibulak (Taimagambetov 2009).
} 


\section{Potsherds}

The Bronze Age is the period most represented, with $45 \%$ of the total potsherd finds. These are most abundant in the mid-low Naryn $(Z-3.1,3.2)(80 \%$ of the total Bronze Age count) and most scarce in the Bakanas delta head (Z-2.1, 2.2) (4\%). The highest occurrence of Bronze Age material within the zonal assemblage is found in the Akdala delta head (Z-1.2) (100\%), in the Mid-Naryn (Z-3.1) (57\%) followed by the Low Naryn (Z-3.2) (52\%).

Bronze Age sherds consist of fragments of handmade (molded, slab joined) coarseware with thick walls, gray and reddish paste with high sand inclusion and generally belonging to open forms (pot or jar shaped) characteristic of the Andronovo and Final Bronze potteries of Semirechie. Diagnostic sherds constitute $28 \%$ of the Bronze Age material. Half of them (14\%) provide morphological information, the other half are sherds with fabric impressions $(7 \%)$ or ornaments $(7 \%)$ consisting of incised patterns (1/3) or applied 'pearls' $(2 / 3)$.

Among the fragments with incised patterns, some are found almost identical in stratified layers in the Semirechie region dated by absolute chronology. Pieces with bands of striated triangles carved on the neck (Photo $4.2 \mathrm{~b}$ ) and with a crest-shaped groove and nail incisions (Photo 4.2d) are found in the second Bronze Age layer of the settlement Turgen II in the upper Turgen valley $(2.285 \mathrm{~m}$ asl, $70 \mathrm{~km}$ east of Almaty) dated by 14C (fireplace) to the XVIII-XVI centuries BC (Gass and Goryachev 2016). Although, on the basis of Late Bronze finds in the same (very disturbed) layer, A. Goryachev would prefer to date such potsherds to the end of the Late Bronze, at the turn of the XIII-XI centuries BC (Goryachev 2013).

Another fragment with zigzag double line and nail incisions around the rim (Photo 4.2c) has an almost analogical piece in the inventory of the enclosure 8 of Bylkyldak I in the Upper Atasu river valley (Margulan et al. 1966), which constitutes one of the typical mixed Alakul-Federovo monuments dated to the first half of the II millennium $^{12}$ (Molodin et al. 2014). The fragment is also similar to potteries from the enclosure I of the Tamgaly I cemetery dated by ESR (pot sediments) to the XIII century BC (Rogozhinskii 1999).

The other, prevailing, group of ornamented sherds consists of applied 'pearl' ornaments or holes around the neck (Photo 4.2f), which in the Semirechie inventory are typical for the Late-Final Bronze period. This decoration typifies the BegazyDandybay and Dongal cultures met in the pre-Iron Age layers in numerous sites of the region (settlements Turgen II, Butakty, Oi-Jailau, Tasbas, Tamgaly I, Begash) and radiometrically dated to the XIV-IX centuries BC (Doumani 2014).

Iron Age potsherds are materially different from the previous period by being less coarse, fired at higher temperature, generally thinner and smoother, of predominant orange color, with a wider variety of sizes and forms, often provided with handles,

\footnotetext{
${ }^{12}$ Although this emblematic Atasu monument still lacks radiometric data, a neighbor burial of the next cultural phase (Begazy-Dandybay) has recently been absolutely dated to the XV-XIII centuries BC (Beisenov 2015).
} 
and with much rarer decoration. They are found in clusters together with the Bronze Age finds, witnessing continuity of habitats between the two periods.

Iron Age material is slightly less represented than Bronze Age material (36\% of the total) and found in all zones. By number it is more abundant downstream, but in lesser number than Bronze Age and constituting 35\% of all finds of the area; and then closer to delta heads [mainly on the Ili-upper right bank (Z-1.1) and in the upper Orta-Bakanas-upper (Z-2.1)] where it exceeds by number Bronze Age items constituting respectively $51 \%$ and $56 \%$ of the zonal assemblage. ${ }^{13}$

Iron Age diagnostic sherds are characterized by more morphological features like handles and spouts, quasi absence of ornament (single case of red slip ware), and by textile imprints ( 11 out of 52 imprinted sherds).

Medieval potsherds are 4 times less abundant than Bronze Age material, although found in all zones, with highest count in the low (44\%) and middle Naryn (18\%) $(Z-3.2,3.1)$ and the highest percentage of the zonal assemblage in the Naryn estuary (Z-3.3) (61\%) and in the upper Orta Bakanas (Z-2.1) (56\%). They are generally found (not always exposed by rodents) on the surface and borders of takyrs (claypan), pointing to new strategies of land and water use; and less on terraces of recently desiccated river branches.

The manufacture of Medieval potsherds carry information about sub-periods. No potsherds dated to the early Turkic period have been identified during our surveys. Characteristic pieces of the Karakhanid period (IX-XII centuries AD) may represent the only medieval demographic peak in the delta, contemporary with the building of a longitudinal network of forts along the Ortasu paleocourse. No trace of postMongol occupation has been found. The data quoted above may indicate that during Medieval times habitation was concentrated between piedmonts and alpine pastures, with the delta mainly used as a way station on interregional roads.

Ethnographic (Late Medieval, last 4 centuries) Kalmyk and Kazakh materials dated to the XVII-XIX centuries AD represent a small $1.4 \%$ of the finds, with the highest percentage of the zonal assemblage in the Mid-Akdala (Z-1.5) (31\%). This was a pluvial period, when the main delta switched to its modern location and as most probably did human habitats, in areas still unexplored to the west of our research polygon.

Slag

Few samples of slag from iron and copper ore are found in 3 zones of the Bakanas delta: at the delta head and in the middle and lower course of the Naryn distributary (Z-3.1, 3.2, 3.3). Slag and a smelting workshop have been recorded in the southeastern outwalls of the medieval fort of Aktam and around the northernmost fort of Barkhan (Baipakov 1998).

\footnotetext{
${ }^{13}$ In the upper Orta-Bakanas (Z-2.1) have been collected just 10 pieces of Early Iron potsherds that anyhow constitute the majority of the total 18 finds.
} 
Similar copper slag has been found and studied by geologists at the eastern edge of the Saryesik-Atyrau desert, on the western bank of the Karatal river (Miroshnichenko and Tetryakov 1962). Due to concomitant surface occurrence of Bronze potsherds, both authors link the findings to some Bronze Age campsites found in the area. Their slag analyses revealed a mineral content similar, although specific, to the content found in the major copper deposits at the north (Kungrad, Sayak, Aktogai) and south (Malaisary, Altyn-Emel, Tekeli) of the Balkhash-West Jungar metallogenic belt.

The abundance of fuel-mainly saxaul bushes_-might have played a major role in the use of the delta as a favored smelting workshop for metal ore mined in the mountain zone or even on the northern bank of the Balkhash lake.

\section{Other Metal and Stone Objects}

In the lower Akdala branch (Z-1.6), in a locus assemblage including a diagnostic Bronze Age sherd, a copper bead (1.1 cm diam.) was found (Photo 4.3g) which is characteristic for the Bronze Age layers of Semirechie (Gass and Goryachev 2016). And in two different loci of the Lower Naryn (Z-3.3) a round copper foil $(5 \times 5 \mathrm{~cm})$ and a dozen of fairly corroded iron fragments (average of $2.5 \mathrm{~cm}$ ) were found that are difficult to assign chronologically.

On the right bank of the upper Ili (Z-1.1) a hook-shaped iron accessory $(3.5 \mathrm{~cm}$ length) looking like a belt hanger and a piece of iron $(5 \times 3.5 \mathrm{~cm})$ resembling a cauldron fragment were collected. Both iron artifacts, being only superficially corroded, have been dated to the ethnographic period.

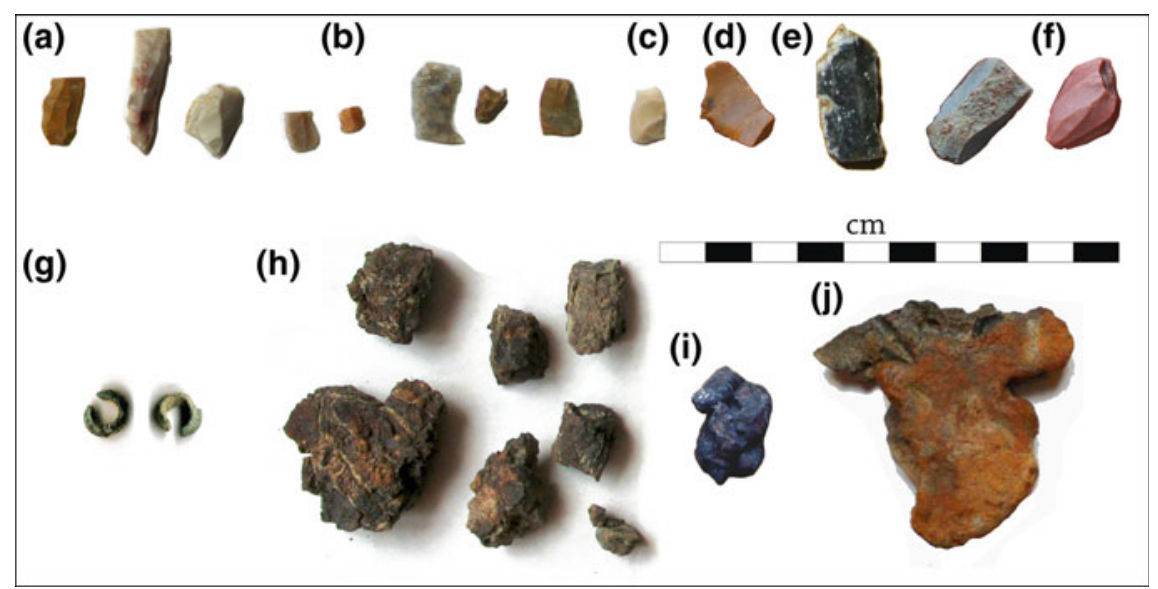

Photo 4.3 Stone and metal finds. a-f Microliths (a Akdala-head Z-1.2, b-c Akdala-low Z-1.6, d Naryn-upper Z-2.2, e Naryn-mid Z-3.1, f Naryn-low Z-3.2), g copper bead (recto-verso, Akdalalow Z-1.6), h iron slag (Naryn-upper Z-2.2), i iron or copper slag (Naryn-mid Z-3.1), j iron slag (Naryn-low Z-3.2) 
Among the stone artifacts, fragments of a crescent shaped grinder $(10 \times 4 \mathrm{~cm})$ and of a triangular whetstone $(4.2 \times 2 \mathrm{~cm})$, both made from sandstone, were recorded in the Low Naryn (Z-3.2). They have been dated to the Iron Age by analogy to similar artifacts typical for that period in Semirechie.

\subsection{Conclusions}

The exposed results lead us to discuss the correlation between climate phases, hydrological events and distribution of artefacts and habitats within the central part of the Ili delta system. In that way we will propose a preliminary reconstruction of the process of early human colonization and subsequent historical development in the region.

In arid zones like the Pre-Balkhash region, the evolution of both delta distributaries and human groups largely depends from water availability and climate. Among the climate variables, determinant is the fluctuation of the amount of precipitation, which alternates pluvial and arid phases.

In Central Asia as a whole and in particular in South Kazakhstan, average precipitation values before and after $3000 \mathrm{BP}$ grew from about $280 \mathrm{~mm}$ per year to $310 \mathrm{~mm}$ per year in average. Most arid phases are detected at 4.6-3.8, 3.3-3.0 and 0.8-1.0 ka BP, followed by 3 pluvial phases (Fig. 4.4). The shift from the Uzunaral to the Bakanas paleodelta (with the activation of upper Ili river course and of the Naryn delta distributary) happens around 4000 BP, and the shift from the Bakanas to the modern Ili delta at $700 \mathrm{BP}$. Both events are situated at the transition from an arid to a pluvial phase.

The process of colonization of the Ili delta performed in two stages, before and after 2000 BC. It might have started during the transition between the Eneolithic and early Bronze period on the upper part of the delta system (Paleo-Ili river segment and upper distributaries of the most ancient deltas, Z-1.2, 1.3, 1.4) as witnessed by the presence of numerous microliths and very fragmented and abraded undecorated sherds. Following the activation of the Bakanas delta around $2000 \mathrm{BC}$, colonization spread all along the newly active delta distributaries, in particular the upper and lower Naryn course $(Z .3 .1,3.2)$, becoming predominant in the lower reaches.

Protagonists of the first phase could have been groups of hunter-fishermen and early shepherds, possibly semi-settled in niches of the upper course. The settlers of the second phase (to which the bulk of the Bronze Age sherds is attributed) were groups already acquainted with seasonal transhumances between summer camps in mountain meadows, autumn and spring transitions across piedmonts, and winter camps in the green alluvial plains of the lower part of the delta system. In addition, the presence of permanent settlements and irrigated fields is not excluded. Clear evidences of farming activities with the cultivation of barley, wheat, millet and green peas dated to the second millennium $\mathrm{BC}$ have been documented in the mountain meadows of Tasbas (in the Djungarian Alatau, $200 \mathrm{~km}$ east of the delta head) (Spengler et al. 2014). 
The finding of copper and bronze slag on the western terraces of the Karatal river and around medieval habitats in the central part of the paleodelta testifies the dual activity of such groups, as herder-miners exploiting the summer pastures and mines of the mountain zone and as shepherd-metallurgists using the winter grasses and fuel of the lower delta.

The Bronze Age as a whole (due to its length) and, in particular, the Naryn course (due to its long endurance as first active Bakanas distributary), shows the largest density of cultural remains and human habitats among all the periods and areas under study.

Starting from the first half of the first millennium BC until the turn of our era, there is a rise in precipitation and river flow, and the pastoralist and metallurgist patterns of the former millennium adapt to new very mobile animal assemblages (sheep and horse) and to iron ore. The number of surface artefacts attributed to that Early Iron period is slightly less than the preceding one and their distribution favors the upper regions of the deltas.

We are faced with difficulties explaining why from the start of our era until the Medieval Warm Period (MWP), the number of cultural remains suddenly drops to a third of the Iron Age, pointing to a diminution of human presence in the delta region, in particular in the upper reaches of the deltas. The causes can be variously attributed to economical or climatic factors, probably concomitant: the development in the piedmont area of mixed-farming activities, allowing for demographic concentration and a more settled way of life in these areas; or to climate conditions that reduced the desert biomass or at the contrary and more probably, made it inaccessible by excessive snow cover.

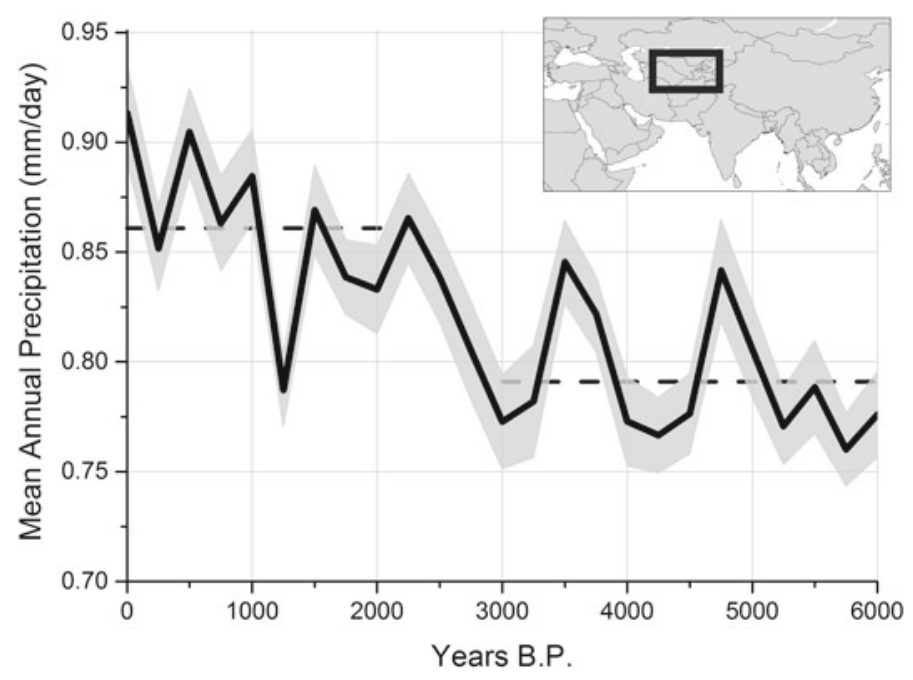

Fig. 4.4 Evolution of precipitation values (mm/year) in West Central Asia during the last $6 \mathrm{ka}$ (Hill 2019) 
Certainly the lower reaches of the deltas are again populated, both by camps and interregional caravan routes, during the MWP (900-1200 AD), i.e. at the peak of urbanization of the piedmonts under Karakhanid rule, to which are attributed most of the medieval cultural findings.

The delta seems to be again abandoned in the Post-Mongol period, in spite of the total dismantlement of the urban complexes of the entire Semirechie region and the pastoral conversion that followed. But now such event can find a simple explanation in the decreasing use by a part of the new pastoralist groups of Semirechie, from the XIII century AD to the Kalmyk colonization of the XVIII century AD, of ceramic wares that represent the main markers of our spatiotemporal analysis.

Following the first ethnographic accounts concerning the XVIII century AD, we find again in the delta a complex and detailed scenario of very mobile transhumant stratified pastoralist clans and farming groups of different ethnic attribution: Kazakh, Kalmyk, Jalair etc. Their environmental context is also quite mobile and changeable: the Bakanas delta is at that time desiccated and the modern Ili delta starts its geological evolution.

\section{References}

Abdrasilov, S. A. (1993). Ruslovye protsessy na deltovykh uchasrkakh rek pri gidrotechnicheskom stroitelstve (na primere delty reki Ili). [Fluvial processes on deltaic sites of rivers under hydroengineering construction (using the example of the Ili river delta)]. Doctorate thesis, Moscow, pp. 19-25.

Akishev, K. A., \& Baipakov, K. M. (1969). Zemli drevnogo orosheniya v nizovyakh r.lli [Lands of ancient irrigation in the lower Ili river]. In S. P. Tolstov, B. V. Andrianov (Eds.), Zemli drevnogo orosheniya i perspektivy ikh selkokhozyaistvennogo ispolzovaniya [Lands of ancient irrigation and perspectives of their agricultural use] (pp. 81-95). Moscow-Nauka.

Aristov, N. A. (1894). Opyt vyyasneniya etnichskogo sostava kirgiz-kazakov Bolshoi ordy I karakirgizov na osnovanii rodoslovnykh skazanii i svedenii o rodovykh tamgakh, a takzhe istoricheskikh dannykh I nachinayuschikhsya antropologicheskikh issledovanii [Attempt to explain the ethnic structure of the Kirghiz-Kazakhs of the Great Horde and of the Karakighizs on the basis of the genealogical narratives and testimonies on the existing clan symbols as well as of historical data and early anthropological investigations]. Zhivaya Starina. Issue III-IV, St Petersburg, pp. 391-486.

Arkheologicheskaya karta Kazakhstana [Archaeological Map of Kazakhstan]. (1960). Alma-Ata, p. 198.

Aubekerov, B., Nigmatova, S., \& Sala, R. (2009). Prehistorical and historical stages of development of the Balkhash lake. In J. Kubota, M. Watanabe (Eds.), Reconceptualizing cultural and environmental change in Central Asia. An historical perspective on the future (pp. 49-76). Kyoto: RIHN.

Baipakov, K. M. (1998). Srednevekovye goroda Kazakhstana na Velikom Shelkovom puti [Medieval towns of Kazakhstan on the Silk Road] (pp. 180-186). Almaty: Gylym.

Baipakov, K. M., \& Groshev, V. A. (1993). Novye dannye o zemlyakh drevnego orosheniya r. Ili [New data on the lands of ancient irrigation in the lower Ili river]. In V. F. Zaibert (Ed.), Problemy 
rekonstruktsii khozyaitsva i tekhnologii po dannym arkheologii [Problems of economical and technological reconstruction based on archaeological data] (pp. 32-42). Petropavlosk.

Baipakov, K., Efstiveev, B. C., Pachikin, K., \& Savelieva, T. (2001). Ekologo-arkheologicheskie issledovaniya V yuzhnom Pribalkhshye (severo-vostochnoe Semirech'e) [Ecologicalarchaeological researches in the southern Pre-Balkhash, NE Semirechie]. Archaeology, Ethnography and anthropology of Eurasia, 2(6), 112-122.

Beisenov, A. Z. (2015). Pamyatniki verkhovev reki Atasu v Tsentralnom Kazakhstane [Monuments of the upper river Atasu in Central Kazakhstan]. Vestnik Tomskogo gosudarstvennogo universiteta. Istoriya, 3(35), 111-122.

Chiba, T., Endo, K., Sugai, T., Haraguchi, T., Kondo, R., \& Kubota, J. (2016). Reconstruction of Lake Balkhash levels and precipitation/evaporation changes during the last 2000 years from fossil diatom assemblages. Quaternary International, 397, 330-341. https://doi.org/10.1016/j.quaint. 2015.08.009.

Coque, B., Debaine, F., \& Hazemann, J. (2000). L'eau dans le désert du paléodelta de l'Ili (Sud du Lac Balkhash, Kazakhstan): bilan d'une reconnaissance géomorphologique et apport de la télédétection. Bulletin de l'Association de géographes français, 77e année, 2000-1 (mars). L'eau dans les milieux arides et semi-arides. La mondialisation de la distribution (pp. 3-9).

Deom, J.-M., \& Sala, R. (2012). Geographical, paleoecological and sociopolitical factors of the areal distribution of the Saka kurgans of Semirechie. In Proceedings of the international scientificpractical seminar "historic cultural heritage and modern culture" (pp. 28-34). Almaty: Service Press.

Deom, J.-M., Sala, R., Aubekerov, B., \& Nigmatova, S. (2009). Land and water use in the IliBalkhash basin from Paleolithic to Modern Times. In Kubota, J., \& M. Watanabe (Eds.), Reconceptualizing cultural and environmental change in Central Asia. An historical perspective on the future (pp. 105-115). Kyoto: RIHN.

Deom, J.-M., Aubekerov, B., Sala, R., \& Nigmatova, S. (2012). Quaternary evolution of the human habitats in the Ili-Balkhash region from paleolithic to modern times. In J. Kubota \& M. Watanabe (Eds.), Toward a sustainable society in Central Asia: An historical perspective on the future (pp. 49-58). Kyoto: RIHN.

Doumani, P. (2014). Bronze age potters in regional context: Long-term development of ceramic technology in the Eastern Eurasian steppe zone. Ph.D. thesis, Arts \& Sciences Electronic Theses and Dissertations, p. 336. Washington University in St. Louis.

Dzhurkashev, T. N. (1972). Antropogenovaya istoriya Balkhash-Alakolskoi vpadiny [The Quaternary history of the Balkhash-Alakol depressions]. Alma-ata: Nauka.

Endo, K., Sugai, T., Haraguchi, T., et al. (2012). Lake level change and environmental evolution during the last 8000 years mainly based on Balkhash Lake cores in Kazakhstan, Central Eurasia. In J. Kubota, \& M. Watanabe (Eds.), Toward a sustainable society in Central Asia: An historical perspective on the future (pp. 35-48). Kyoto: RIHN.

Erofeeva, I. V. (2008). Anrakhaiskii treugolnik: istoriko-geograficheskii areal i khronika Velikogo srazheniya [The Anrakhai triangle: Historico-gegraphical area and chronicle of a great battle] (pp. 287-288). Almaty: Daik-Press.

Frachetti, M., Maryashev, A. N., \& Doumani, P. (2014). Poseleniya gornoi chasti Semirechya i voprosy ekologii i khozyaistva v Bronzovom veke [Settlements in the mountain part of Semirechie and the ecological and economical questions of the Bronze Age]. News of the National Academy of Sciences of the Republic of Kazakhstan, Series of Social and Human Sciences, 5(97), 15-20.

Gass, A. (2016). Das Siebenstromland zwischen Bronze- und Früheisenzeit, Eine Regionalstudie. Mit Beiträgen von Jörg Faßbinder und Julia Gresky. Topoi Berlin Studies of the Ancient World 28, Berlin, Boston: De Gruyter.

Gass, A., \& Goryachev, A. A. (2016). K voprosu o tipologii i khronologii mogilnikov epokhi bronzy v vysokogornoi zone Zailiiskogo Alatau [On the typology and chronology of Bronze Age cemeteries on mountainous area of the Trans-Ili Alatau]. Vestnik of NGU, Series History and Philology, Archaeology and Ethnography, 15(5), 85-123. 
Goryachev, A. A. (2013). Voprosy tipologii i khronologii poselenii epokhi bronzy sklonakh Zailiiskii Alatau [About the typology and chronology of the Bronze Age settlements in the slopes of the Zailiiskii Alatau]. In A. Z. Beisenov (Ed.), Begazy-Dandybaevskaya kultura Stepnoi Evrazii (pp. 348-370). Almaty.

Hill, D. (2019). Climate change and the rise of the central Asian Silk Roads. In Socio-Environmental Dynamics along the Historical Silk Road (in this book).

Kostenko, N. N. (1978). Chetvertichnye otlozheniya Kazakhstana i prilegayoushykh territorii soyuznikh respublik [Quaternary deposits of Kazakhstan and adjacent territories of the Union Republics], Moscow.

Levick, B., Laudisoit, A., Wilschut, L., Addink, E., Ageyev, V., Yeszhanov, A., et al. (2015).The perfect burrow, but for what? Identifying local habitat conditions promoting the presence of the host and vector species in the Kazakh Plague System. PLoS One, 10(9).

Macklin, M. G., Panyushkina, I. P., Toone, W. H. J., et al. (2015). The influence of Late Pleistocene geomorphological inheritance and Holocene hydromorphic regimes on floodwater farming in the Talgar catchment, southeast Kazakhstan, Central Asia. Quaternary Science Reviews, 129, 85-95.

Margulan, A. K., Akishev, K. A., Kadirbaev, M. K., \& Orazbaev, A. M. (1966). Drevnyaya Kul'tura Tsentral'nogo Kazakhstana [The Ancient Culture of Central Kazakhstan] (p. 112). Almaty: Nauka.

Marikovskii, P. I. (1982). Tam, otkuda ushli reki [There, where water went away]. Moscow: Mysl.

Markofsky, S. (2014). When survey goes east: Field survey methodologies and analytical frameworks in a Central Asian context. Journal of Archaeological Method and Theory, 21(4), 697-723.

Miller, G. (2014). O 66-ti godakh zhizni sovetskogo nemtsa v Sovetskom Soyuze. (1928-1994). Memuary i rasskazy o plokhikh i neskolko luchikh vremenakh [About 66 years of life of the Soviet Germans in the Soviet Union. Memoirs and stories about bad and some better times] (p. 64). Rosenheim.

Miroshnichenko, L. A., \& Tetryakov, V. G. (1962). O medenosnykh shlakakh v peskakh Sary-IshikOtrau [About copper ore slag in the Sary-Ishik-Otrau desert]. Vestnik AN KazSSR, 8, 88-90.

Molodin, V. I., Epimakhov, A. V., Marchenko J. V. (2014). Radiouglerodnaya khronologiya epokhi bronzy Urala i yuga Zapadnoi Sibiri: printsipy i podkhody, dostijeniya i problemy [Radiocarbon chronology of the Urals and south of Western Siberia Bronze Age cultures: principles and approaches, achievements and problems] Vestnik of NGU, Series History and Philology, Archaeology and Ethnography, 13(3), 136-167.

Mushketov, I. V. (1886). Turkestan. Geologicheskoe i orograficheskoe opisanie po dannym, sobrannym v puteshestviyakh c 1874 po 1881 [Turkestan. Geological and orographical descriptions from data collected during travels between 1874 and 1881]. St Petersburg.

Palgov, N. N. (1932). Cherez Pribalkhashskie peski Sary-Ishik Otrau [Across the Pre-Balkhash sands of the Sary-Ishik-Otrau desert]. Izvestiya Geograficheski obschestvo SSSR, 64(6), 480-498.

Platonov, L. I. (1959). O proiskhozhdenii Kapchagaiskogo usheliya na r.Ili [On the origins of the Kapchagai gorge on the river Ili]. Almaty.

Rogozhinskii, A. N. (1999). Mogilniki epokhi bronzy urochischa Tamgaly [The Bronze Age cemetery of Tamgaly]. In Istoriya and arkheologiya Semirechya [History and Archaeology of Semirechie] (p. 21). Almaty.

Rumyantsev P. P. (Ed.) (1913). Materialy po obsledovaniyu tuzemnogo $i$ russkogo starozhil'cheskogo khozyaystva i zemlepol'zovaniya v Semirechenskoy oblasti. Tom 4. Vernenskiy uyezd. Kirgizskoye khozeystvo. [Materials on the survey of native and old Russian economy and land use in the Semirechye region. Volume 4. Vernensky County. Kirgiz economy] Part 2. St Petersburg, pp.185 and 223.

Rybin, N. G. (1955). Sukhie rusla drevnei reki Ili-Bakanasy [Dry channels of the ancient river Ili-Bakanas]. Izvestiya Akademii Nauk Kazakhskoi SSR, seriya geologicheskaya, 19(157), 152-161.

Sala, R., Deom, J.-M., Nigmatova, S., Endo, K., \& Kubota, J. (2016). Soviet, recent and planned studies of the behavior of the Balkhash lake. News of the National Academy of Sciences of Kazakhstan, series of Geology and Technical sciences, 2(416), 76-86. 
Sato, A., Sugai, T., Endo, K., Kondo, R., Shimizu, H., et al. (2013). The development of sand dunes around Lake Balkhash and Ili delta in Southeast Kazakhstan (Poster presentation). In PAGES GOA 2013, 4th OSM (13-16th Feb), program and abstracts (pp. 190-191).

Shimizu, H., Sugai, T., Sato, A., Kondo, R., Endo, K., et al. (2012). Late Holocene fluvial landform chronology and paleo-climate in the middle basin of Ili River, Kazakhstan. In Japan Geoscience Union Meeting.

Shimizu, H., Sugai, T., Sato, A., \& Endo, K. (2015). The age and evolution of fluvial landscape in the middle basin of Ili River, Kazakhstan. In Annual meeting of the association of Japanese geographers. Spring 2015 (in Japanese).

Spengler, R., Frachetti, M., Doumani, P., Rouse, L., Cerasetti, B., Bullion, E., \& Mar'yashev, A. (2014). Early agriculture and crop transmission among Bronze Age mobile pastoralists of central Eurasia. Proceedings of the Royal Society of London B: Biological Sciences, 281, 20133382.

Taimagambetov, J. K. (2009). Ob issledovanii stoyanok kamennogo veka v okrestyakh Almaty [On the research of Stone Age campsite around Almaty]. In S.A. Zhakishev (Ed.), Teoreticheskie i prakticheskie aspekty sotsialno-ekonomicheskogo i politicheskogo razvitiya Respubliki Kazakhstan, Tsentralnoi Azii i stran SNG: sbornik materialov mezhdunarodnoi nauchno-prakticheskoi konferentsii (pp. 217-222). Almaty.

Vostrov, V. V., \& Mukanov, M. S. (1968). Rodoplemennoi sostav i raselenie kazakhov (konets XIXnachalo XX v.) [Tribal composition and distribution of the Kazakhs (end XIX-early XX AD)], Alma-Ata: Nauka.

Vyatkin, M. K. (1948). O geomorfologii i nekotorykh momentakh noveishei geologicheskoi istorii yuzhnogo Probalkhashya [On the geomorphology and several moments of recent geological history of the southern Pre-Balkhash]. Vestnik ANKazSSR, 8(41), 3-16.

Wilschut, L. I., Laudisoit, A., et al. (2013). Mapping the distribution of the main host for plague in a complex landscape in Kazakhstan: An object-based approach using SPOT-5 XS, Landsat 7 ETM+, SRTM and multiple Random Forests. International Journal of Applied Earth Observation and Geoinformation, 23, 81-94. https://doi.org/10.1016/j.jag.2012.11.007.

Open Access This chapter is licensed under the terms of the Creative Commons Attribution 4.0 International License (http://creativecommons.org/licenses/by/4.0/), which permits use, sharing, adaptation, distribution and reproduction in any medium or format, as long as you give appropriate credit to the original author(s) and the source, provide a link to the Creative Commons license and indicate if changes were made.

The images or other third party material in this chapter are included in the chapter's Creative Commons license, unless indicated otherwise in a credit line to the material. If material is not included in the chapter's Creative Commons license and your intended use is not permitted by statutory regulation or exceeds the permitted use, you will need to obtain permission directly from the copyright holder.

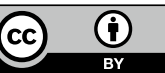

